\title{
Perceptions and Attitudes towards Sustainable Development among Malaysian Undergraduates
}

\author{
Balamuralithara Balakrishnan ${ }^{1}$, Fumihiko Tochinai ${ }^{2} \&$ Hidekazu Kanemitsu ${ }^{2}$ \\ ${ }^{1}$ Sultan Idris Education University, Malaysia \\ ${ }^{2}$ Kanazawa Institute of Technology, Japan \\ Correspondence: Balamuralithara Balakrishnan, Sultan Idris Education University, Malaysia. E-mail: \\ balab@fskik.upsi.edu.my
}

Received: October 7, 2019

Accepted: November 10, 2019

Online Published: November 13, 2019

doi:10.5430/ijhe.v9n1p44

URL: https://doi.org/10.5430/ijhe.v9n1p44

\begin{abstract}
This paper reports the findings of the perceptions and attitudes towards sustainable development among Malaysian undergraduates. The study was carried out involving 154 undergraduates from five universities in Malaysia. This research was conducted based on a survey whereby the respondents were given a questionnaire to gauge their perception and attitude towards sustainable development. The output of the analyses showed that the respondents have positive perceptions and attitudes towards all sustainability dimensions-environmental, economic, and social-except for economic and social bound issues. These findings suggest that the educators who are involved in sustainable development education need to focus on economic and social bound aspects. Overall, the findings showed that the sustainable development education in higher education institutions has cultivated an appropriate sense of responsibility towards sustainability among their undergraduate students. As such, this investigation serves as a cornerstone to which the current paradigm of sustainable development education can be examined for further improvement by related stakeholders.
\end{abstract}

Keywords: sustainable development education, perception, attitude, undergraduates

\section{Introduction}

According to Brundtan (1987), sustainable development (SD) is defined as "the development that meets the needs of the present without compromising the ability of the future generations to meet their needs" (p. 8). Practicing sustainable development is essential to protect our world from any developments that could cause harm to human beings and the environment. Sustainable development is comprised of three main dimensions that are related to the quality of life: the social, the economic, and the environmental dimensions (Leal Filho et al., 2018). These dimensions are pivotal in determining humanity's way of life and should be given utmost priority regarding any activities carried out. Sustainable development has become an essential element in every nation's policymaking, and this is due to the rapid developments we are currently witnessing, which involves a significant trade-off between environmental sustainability and the extraction and utilization of natural resources.

In 2015, 193 countries convened to adopt the 17 Sustainable Development Goals (SDGs) drafted by the United Nations General Assembly, to be achieved by the year 2030. These goals cover all three dimensions of sustainability previously mentioned (Saner et al., 2019). In order to reach these goals of sustainability, an individual's perception and attitude of SD needs to change, and this can be achieved through the means of education (Kanapathy et al., 2019). Education plays an important role in spreading the necessary knowledge, skills, and values which are vital in contributing to SD. Zwickle et al. (2014) have stated that future generations-especially those pursuing studies in higher education institutions - should play a vital role in serving the well-being of humanity and protecting the environment. This realization among youths will help their respective countries in achieving the 17 SDG goals by 2030.

Education of Sustainable Development (ESD) is one way of spreading the ideas and principles of SD to multiple individuals via education (Kopnina \& Meijers, 2014). Al-Naqbi and Alshannag (2018) have stated that ESD is a platform for integrating the appropriate knowledge, skills, and values to infuse the fundamental concepts of SD among undergraduates. Furthermore, the authors also mention that higher education institutions are important places to develop the necessary perceptions and attitudes among future professionals toward SD, which ultimately helps 
pave the way for humanity to achieve the goals of SD. Moore (2005) has also mentioned that higher education institutions play an important role in spearheading ESD.

An individual's perception and attitude towards SD can be developed through the cognitive and affective domains of learning, in which one's perception is determined by the cognitive domain, while one's attitude is determined by the affective domain (Chaiken \& Baldwin, 1981). Mulder (2017) has mentioned that one's perception and attitude towards SD is not only determined by education, but it may also be determined by other external factors such as living environment and society. Broady and Ryu (2006) have asserted that a graduate level education in SD could influence the level of action taken by the students to be sustainable.

The ESD in Malaysian higher education institutions has progressed well, as students have been exposed to this topic through a variety of programs. Sustainable development is one of the main components of the Malaysian Higher Education Blueprint (Sivapalan, 2016) whereby every higher education institution in Malaysia takes the initiative to move towards developing a more sustainable campus and, most importantly, introduces ESD to undergraduates. However, the levels of perception and attitude toward SD among Malaysian undergraduates is not a well-researched area. The studies that are available on ESD in Malaysian higher education institutions concentrate on assessing the level awareness of the undergraduates towards SD that were conducted in studies by Zainordin et al. (2017) and Wee (2017). Moreover, Reza (2016) has mentioned that although the current ESD in Malaysia has developed the students' knowledge and responsibilities toward sustainability, this has not been verified in any studies.

Thus, with this motivation, we are going to gauge the level of perception and attitude towards sustainability among Malaysian undergraduates. The findings of this study could be the cornerstone for interested stakeholders to take another look at the effectiveness of the current ESD system that is practiced in their respective institutions.

\section{Education of Sustainable Development in Malaysian Higher Education Institutions}

Malaysia is a country that is situated in the Southeast Asia region and consists of 30 million people. Malaysia is a multiracial and multicultural country which constitutes Malays, Chinese, Indians, Kadazan, Iban, and others. The Malays are majority (around 60 per cent), followed by Chinese ( 25 per cent) and Indians ( 7 per cent), while others represent about 8 per cent of the total Malaysian population. The population consists of a wide diversity in language, culture, customs, and religious beliefs.

The ESD in higher education institutions can occur in many ways. Some institutions use a formal learning approach with organized and systematic content and a syllabus on SD. However, other universities use an informal learning approach by incorporating experiential learning. In Malaysia, the Ministry of Education has put a great deal of effort into introducing the issues related to SD in tertiary institutions throughout all programs, regardless of disciplines, either in a subject dedicated specifically to SD or in a topic of a subject which focuses on SD. Thus, it can be stated that sustainable development issues comprising the social, economic, and environmental dimensions have been addressed in Malaysian ESD.

At the Universiti Sains Malaysia (USM), a course titled 'Sustainability Issues, Challenges and Prospects' has been offered to all USM undergraduates (Wee, 2017). In all engineering programs at the tertiary level, engineering undergraduates will be exposed to SD in both technical and non-technical subjects, as it is part of the accreditation requirements by the Malaysian accreditation body (Aziz et al., 2012). While for students in other programs, SD concepts have been instilled through topics of a subject related with SD.

Some Malaysian higher education institutions offer programs that directly address the importance of SD for the future generations. The Universiti Kebangsaan Malaysia (UKM), for example, offers a few programs in the field of environmental development, climate change, and natural resources at both undergraduate and post-graduate levels (Saadation et al., 2012). The Universiti Putra Malaysia (UPM) offers environmental studies programs at all levels. The Universiti Tunku Abdul Rahman (UTAR), a leading private university, named its engineering department the Faculty of Engineering and Green Technology, concentrating on green engineering aligned with the sustainability goals. Another private university, Universiti Selangor (UNISEL), offers an undergraduate program on biodiversity and conservation. These initiatives by higher education institutions in Malaysia clearly shows that these institutions have put effort into addressing the issues of SD and emphasize the importance of ESD to the students.

\section{Research Model}

The research model describing the relations among the variables in this investigation are shown Figure 1. This model facilitates an understanding of the overall objectives of this investigation, which are to examine the effect of SD education on the perceptions and attitudes of undergraduates towards sustainability issues in Malaysia. In this model, 
'perception' was conceptualized based on Direct Perception Theory and 'attitude' was based on Theory of Instruction.

Direct Perception Theory was established by Gregory in 1970 (Hacker, 1991) and explains that an individual actively constructs perception using information. In this study, we examine the construction of perception towards sustainability issues via ESD which the participants of this study acquired in the classroom. Gagne and Dick (1983) have explained that in the Theory of Instruction, attitude is influenced by the acquired internal states that affect the choice of personal action towards some class of things, persons, or events.

With proper perceptions on SD, a positive attitude towards sustainability could be developed. Esa (2010) has found that there is a strong correlation between knowledge and attitude on SD whereby the author found that the more knowledge acquired on SD, the more positive the attitude. Thus, education is rudimentary in developing future generations that will maintain a strong sense of responsibility towards SD.

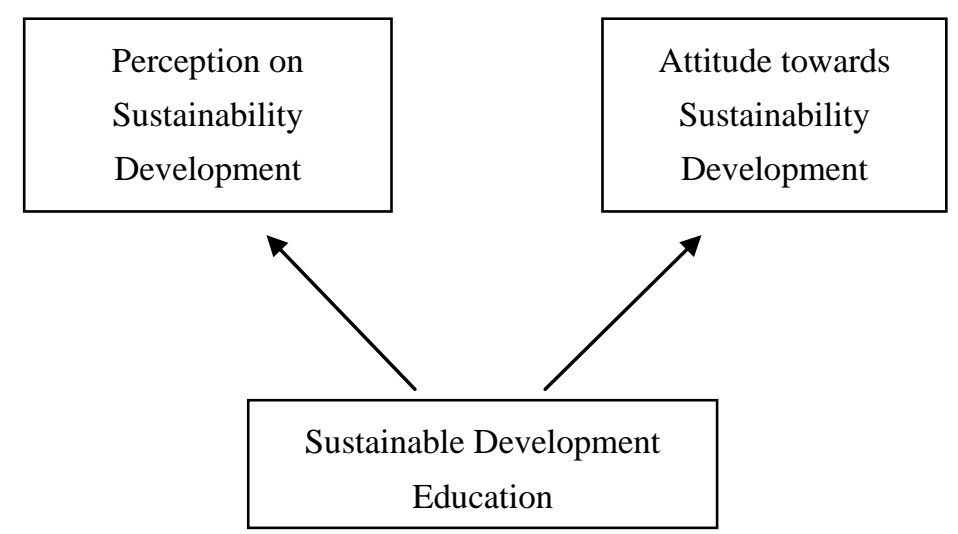

Figure 1. Research Model

Based on this setting, the following research issues were investigated:

R1: The level of perception towards SD among Malaysian undergraduates.

R2: The level of attitude towards SD among Malaysian undergraduates.

\section{Methodology}

This study is focused on the perceptions and attitudes towards SD among Malaysian undergraduates who have received education on SD in their respective undergraduate programs. We recruited a group of respondents consisting of 154 undergraduates, who were randomly selected from five different universities-both public and private-in Malaysia. All the participants have learned a subject or topic on SD from various programs. The recruitment of the participants of this study was facilitated by the commitment and co-operation given by respective lecturers of the selected universities. Table 1 summarizes the information of the respondents' university and number of students for each program. 
Table 1. Respondents' university and number of students for each program

\begin{tabular}{|c|c|}
\hline University & Number of Students \\
\hline & Science \& Technology - 10 \\
\hline \multirow[t]{3}{*}{ University A } & Arts \& Design -10 \\
\hline & Social Sciences -12 \\
\hline & Science \& Technology - 10 \\
\hline \multirow[t]{3}{*}{ University B } & Arts \& Design - 11 \\
\hline & Social Sciences - 10 \\
\hline & Science \& Technology - 10 \\
\hline \multirow[t]{3}{*}{ University $\mathbf{C}$} & Arts \& Design - 11 \\
\hline & Social Sciences - 10 \\
\hline & Science \& Technology - 10 \\
\hline \multirow[t]{2}{*}{ University D } & Arts \& Design - 10 \\
\hline & Social Sciences - 10 \\
\hline \multirow[t]{3}{*}{ University $\mathbf{E}$} & Science \& Technology - 11 \\
\hline & Arts \& Design - 10 \\
\hline & Social Sciences - 10 \\
\hline
\end{tabular}

The students were surveyed via an online questionnaire pertaining to the issues being studied. The questionnaire (see Table 2) was divided into two parts; part (A) - assessing the level of perception and part (B) - gauging the level of attitude. Each item of the questionnaire uses a 4-point Likert type scale ranging from 1 (Strongly Disagree) to 4 (Strongly Agree). The scale was used to rank the level of agreement for each statement. The questionnaire gauged the perception and attitude towards sustainability issues and included three key dimensions of sustainability; (i) social (ii) economy and (iii) environment.

For the first part (A), the statements were based on studies of Tuncer (2008) and Al-Naqbi and Alshannag (2018). In this part of the questionnaire, the items were modified according to the needs of the study that evaluated the individual's perception on social, economic, and environmental sustainability issues.

For the items of part (B), the statements were formulated according to Biasutti and Frate (2017). The items focused on assessing the individual's attitude regarding the issues comprising all three dimensions of sustainability.

All items in part (A) and part (B) were rephrased and added to the existing instrument to allow us to examine the relevant factors deemed appropriate.

\section{Results and Discussion}

Data were analyzed using SPSS software. The reliability co-efficient (Alpha Value) for both constructs-perception and attitude — of the collected data were 0.750 and 0.834 respectively, which are deemed reliable (Creswell, 2013). In addition, a Shapiro-Wilk test was conducted, and it indicated that the data were normally distributed.

For the first research issue, R1, assessing the level of perception towards SD among Malaysian undergraduates, the mean scores for items A1 to A22 (referring to Table 1, Part A), ranged from 1.08 (Standard Deviation $=0.24$ ) to 3.82 (Standard Deviation $=0.11$ ). While for the second research issue, R2, which dealt with the respondents' attitudes on SD (as shown in Table 2, Part B), the mean scores for items B1-B12 ranged from 1.32 (Standard Deviation $=0.21$ ) to 3.64 (Standard Deviation $=0.22$ ). 
Table 2. Mean and Standard Deviation for each Items in Part A and Part B

\begin{tabular}{|c|c|c|c|}
\hline No & Item & $\begin{array}{l}\text { Mean } \\
\text { Value }\end{array}$ & $\begin{array}{l}\text { Standard } \\
\text { Deviation }\end{array}$ \\
\hline \multicolumn{4}{|c|}{ Part A: Perception } \\
\hline A1 & $\begin{array}{l}\text { Individuals should receive proper education that teaches the necessary } \\
\text { knowledge, skills, and values for living. }\end{array}$ & 3.45 & 0.14 \\
\hline A2 & $\begin{array}{l}\text { The current generation should ensure the future generation inherits good } \\
\text { health, as today. }\end{array}$ & 3.38 & 0.21 \\
\hline A3 & Gender equality is pivotal to society. & 3.14 & 0.22 \\
\hline A4 & The socio-culture of a society should be prevailed for future generations. & 3.16 & 0.18 \\
\hline A5 & $\begin{array}{l}\text { Protection of the environment is important for current and future } \\
\text { generations. }\end{array}$ & 3.62 & 0.12 \\
\hline A6 & Conservation of biodiversity is pivotal. & 3.58 & 0.13 \\
\hline A7 & $\begin{array}{c}\text { Individuals are responsible for taking care of the environment and its } \\
\text { resources. }\end{array}$ & 3.77 & 0.11 \\
\hline A8 & $\begin{array}{c}\text { Every individual should take necessary actions to curb global warming } \\
\text { issues. }\end{array}$ & 3.82 & 0.11 \\
\hline A9 & $\begin{array}{c}\text { Industrialized countries should provide its people with a high standard of } \\
\text { living. }\end{array}$ & 3.23 & 0.21 \\
\hline A10 & $\begin{array}{l}\text { The over-consumption of natural resources for economic development } \\
\text { does not threaten the welfare of future generations. }\end{array}$ & 1.08 & 0.24 \\
\hline A11 & The income gap between rich and poor individuals should be narrowed. & 3.07 & 0.04 \\
\hline A12 & Equality in business activities is important for the well-being of society. & 1.42 & 0.12 \\
\hline \multicolumn{4}{|c|}{ Part B: Attitude } \\
\hline B1 & Society should promote equal opportunities for males and females. & 3.12 & 0.12 \\
\hline B2 & The contact between different cultures is stimulating and enriching. & 3.14 & 0.09 \\
\hline B3 & The government should provide proper healthcare services to the people. & 3.42 & 0.15 \\
\hline B4 & The government should take responsibility for providing education for all. & 3.47 & 0.06 \\
\hline B5 & $\begin{array}{l}\text { When people interfere with the environment, they often produce } \\
\text { disastrous consequences. }\end{array}$ & 3.64 & 0.22 \\
\hline B6 & $\begin{array}{c}\text { Environmental protection and people's quality of life are directly } \\
\text { interlinked. }\end{array}$ & 3.55 & 0.14 \\
\hline B7 & $\begin{array}{l}\text { Industrial development is less important than environmental and } \\
\text { biodiversity protection. }\end{array}$ & 3.72 & 0.13 \\
\hline B8 & $\begin{array}{l}\text { Biodiversity should be protected at the expense of industrial agricultural } \\
\text { production. }\end{array}$ & 3.54 & 0.15 \\
\hline B9 & $\begin{array}{l}\text { Government economic policies should increase sustainable production, } \\
\text { even if it means spending more money. }\end{array}$ & 3.43 & 0.11 \\
\hline B10 & $\begin{array}{l}\text { People should make more sacrifices to reduce the economic differences } \\
\text { between populations. }\end{array}$ & 1.32 & 0.21 \\
\hline B11 & $\begin{array}{c}\text { Government economic policies should act if a country is wasting its } \\
\text { natural resources. }\end{array}$ & 3.48 & 0.16 \\
\hline B12 & $\begin{array}{l}\text { Reducing poverty is more important than increasing the economic } \\
\text { well-being of the people. }\end{array}$ & 3.08 & 0.05 \\
\hline
\end{tabular}


The mean scores for items A5, A6, A7, and A8 recorded high mean scores (more than 3.5) compared to other items in Part A, and items B5, B6, B7, and B8 were high (more than 3.5) compared to other items in Part B. These mentioned items assessed perceptions and attitudes in the context of environmental sustainability, which clearly indicates that the respondents have a positive perception and attitude towards the protection of the environment and conservation of biodiversity. It is clear from the mean scores of item A10, which had the lowest mean score (Mean Value $=1.08$, Standard Deviation $=0.24)$ referring to Table 2, measured the respondents' perceptions on the trade-off between economic development and environmental protection for future generations, and showed that the respondents have a good view of environmental protection through ESD. The exposure of the importance of environmental sustainability via ESD in their respective institutions has instilled in the students the view that economic development should not be prioritized over environmental sustainability.

On the other hand, for the perception and attitude towards economic and social bound issues, items A12 and B10 showed a low mean score of 1.42 and 1.32 respectively. These findings showed that the respondents were not well exposed on the SD issues through an economic and social lens in their ESD learning processes. Saiz \& Donald (2017) have mentioned that the aspect of social and economic equality in SD has not been given priority. Thus, there should be firm efforts from the educators of ESD to bring these issues to the foreground and educate undergraduates on these aspects in order to fulfill the agenda of SDG 2030.

Overall, the items in both Part A and Part B have recorded positive mean scores, which indicate that the Malaysian undergraduates have positive perceptions and attitudes towards SD. This finding contradicts the results of Zainordin et al.'s (2017) study, which found that the awareness of SD among Malaysian undergraduates was not promising due to lack of exposure and emphasis on SD.

The output of this study shows positive perceptions and attitudes towards sustainable development among the Malaysian undergraduates, especially in the context of environmental issues, and except for certain sustainability aspects that focus on economic and social equality. The results of this investigation clearly show that the sustainable development education in Malaysian higher education institutions played its role effectively in educating the undergraduates on sustainability issues. This is in line with Direct Perception Theory (Hacker, 1991) and Theory of Instruction (Gagne \& Dick ,1983) which claims that perception and attitude of an individual can be developed with the process of acquiring knowledge; in this study, the knowledge has been gained through SD education.

However, in order to achieve the vision of SDG 2030, all SD dimensions need to be exposed to the undergraduates in higher education institutions. Therefore, related stakeholders who design and implement ESD should give equal focus on all elements and issues of sustainability. As mentioned by Al-Naqbi and Alshannag (2018), relevant knowledge and skills that cover environmental, social and economic dimensions of SD are the basis for undergraduates to acquire the fundamental concepts of SD. Zeegers and Clark (2014) have asserted that environmental, social and economic dimensions are the pillar of SD and none of these elements can be ignored.

With appropriate knowledge, skills, and values on SD, future generations, especially current undergraduates, could deal with sustainability issues with a high degree of responsibility. ESD plays a pivotal role in bringing proper perceptions and attitudes towards SD that will drive the undergraduates to take significant action and achieve SD goals. Hence, a holistic approach and action is required to be implemented across all higher education institutions to develop undergraduates who will maintain a strong sense of responsibility towards sustainability issues in Malaysia and other countries as well.

\section{Conclusion}

This study has shown that the ESD in Malaysian higher education institutions has developed positive perceptions and attitudes towards SD among the undergraduates. The dimension related to economic and social bound issues recorded a low mean score, which indicates that the educators of ESD need to expose students to the related issues in ESD classrooms. Proper knowledge, skills, and values gained via ESD are pivotal in shaping the perceptions and developing the attitudes towards SD among the undergraduates that will, ultimately, contribute to achieving the vision of SDG 2030. Higher education institutions play a critical role in promoting SD and developing a future workforce who maintain a sense of responsibility towards sustainable development that will ensure the next generations will be able to live a quality life in an environment conducive to comfort and safety.

\section{Acknowledgement}

This research has been carried out under Rising Star University Research Grant (Research Code: 2019-0124-107-01) provided by Sultan Idris Education University, Malaysia. 


\section{References}

Al-Naqbi, A. K., \& Alshannag, Q. (2018). The status of education for sustainable development and sustainability knowledge, attitudes, and behaviors of UAE University students. International Journal of Sustainability in Higher Education, 19(3), 566-588. https://doi.org/10.1108/IJSHE-06-2017-0091

Aziz, A. A., Sheikh, S. N. S., Yusof, K. M., Udin, A., \& Yatim, J. M. (2012). Developing a structural model of assessing students' knowledge-attitudes towards sustainability. Procedia-Social and Behavioral Sciences, 56, 513-522. https://doi.org/10.1016/j.sbspro.2012.09.683

Brundtland, G.H. (1987), Our Common Future: World Commission on Environment and Development, Oxford University Press, New York, NY.

Brody, S. D., \& Ryu, H. C. (2006). Measuring the educational impacts of a graduate course on sustainable development. Environmental Education Research, 12(2), 179-199. https://doi.org/10.1080/13504620600688955

Biasutti, M., \& Frate, S. (2017). A validity and reliability study of the attitudes toward sustainable development scale. Environmental Education Research, 23(2), 214-230. https://doi.org/10.1080/13504622.2016.1146660

Chaiken, S., \& Baldwin, M. W. (1981). Affective-cognitive consistency and the effect of salient behavioral information on the self-perception of attitudes. Journal of Personality and Social Psychology, 4l(1), 1. https://doi.org/10.1037/0022-3514.41.1.1

Creswell, J. W. (2013). Educational research: Planning, conducting, and evaluating. W. Ross MacDonald School Resource Services Library.

Esa, N. (2010). Environmental knowledge, attitude and practices of student teachers. International Research in Geographical and Environmental Education, 19(1), 39-50. https://doi.org/10.1080/10382040903545534

Gagne, R. M., \& Dick, W. (1983). Instructional psychology. Annual review of psychology, 34(1), $261-295$. https://doi.org/10.1146/annurev.ps.34.020183.001401

Hacker, P. M. S. (1991). Experimental methods and conceptual confusion: an investigation into RL Gregory's theory of perception. Iyyun: The Jerusalem Philosophical Quarterly/289-314.

Kanapathy, S., Lee, K. E., Sivapalan, S., Mokhtar, M., Syed Zakaria, S. Z., \& Mohd Zahidi, A. (2019). Sustainable development concept in the chemistry curriculum: An exploration of foundation students' perspective. International Journal of Sustainability in Higher Education, 20(1), 2-22. https://doi.org/10.1108/IJSHE-04-2018-0069

Kopnina, H., \& Meijers, F. (2014). Education for sustainable development (ESD) Exploring theoretical and practical challenges. International Journal of Sustainability in Higher Education, 15(2), 188-207. https://doi.org/10.1108/IJSHE-07-2012-0059

Leal Filho, W., Azeiteiro, U., Alves, F., Pace, P., Mifsud, M., Brandli, L., \& Disterheft, A. (2018). Reinvigorating the sustainable development research agenda: the role of the sustainable development goals (SDG). International Journal of Sustainable Development \& World Ecology, 25(2), 131-142. https://doi.org/10.1080/13504509.2017.1342103

Mulder, K. F. (2017). Strategic competences for concrete action towards sustainability: An oxymoron? Engineering education for a sustainable future. Renewable and Sustainable Energy Reviews, 68, 1106-1111. https://doi.org/10.1016/j.rser.2016.03.038

Moore, J. (2005). Barriers and pathways to creating sustainability education programs: policy, rhetoric and reality. Environmental Education Research, 11(5), 537-555. https://doi.org/10.1080/13504620500169692

Reza, M. I. H. (2016). Sustainability in higher education: perspectives of Malaysian higher education system. Sage Open, 6(3), 1-9. https://doi.org/10.1177/2158244016665890

Saadatian, O., Haw, L. C., Mat, S., \& Sopian, K. (2012). Perspective of sustainable development in Malaysia. International Journal of Energy and Environment, 6(2), 260-267.

Saner, R., Yiu, L., \& Kingombe, C. (2019). The 2030 Agenda compared with six related international agreements: valuable resources for SDG implementation. Sustainability Science, 1-32. https://doi.org/10.1007/s11625-019-00655-2 
Saiz, I., \& Donald, K. (2017). Tackling inequality through the Sustainable Development Goals: human rights in practice. The International Journal of Human Rights, 21(8), 1029-1049. https://doi.org/10.1080/13642987.2017.1348696

Sivapalan, S. (2016). Engineering education for sustainable development in Malaysia: student stakeholders perspectives on the integration of holistic sustainability competences within undergraduate engineering programmes. In Engaging Stakeholders in Education for Sustainable Development at University Level (pp. 263-285). Springer, Cham. https://doi.org/10.1007/978-3-319-26734-0_17

Tuncer, G. (2008). University students' perception on sustainable development: A case study from Turkey. International Research in Geographical and Environmental Education, 17(3), 212-226. https://doi.org/10.1080/10382040802168297

Wee, M. I., Ariffin, F. N., Ng, T. F., \& Shabudin, A. F. A. (2017). Awareness and Attitudes Towards Sustainable Development Amongst Higher Education Students in Penang, Malaysia. In Handbook of Theory and Practice of Sustainable Development in Higher Education (pp. 49-64). Springer, Cham. https://doi.org/10.1007/978-3-319-47877-7_4

Zeegers, Y., \& Francis Clark, I. (2014). Students' perceptions of education for sustainable development. International Journal of Sustainability in Higher Education, 15(2), 242-253. https://doi.org/10.1108/IJSHE-09-2012-0079

Zainordin, N., Wahi, W., Petrus, M., \& Koh, C. T. (2017). Sustainable Development Attitude: A Study On Perception Among Private \& Public Higher Learning Institutions Student In Malaysia. MATTER: International Journal of Science and Technology, 3(2), 514-524. https://doi.org/10.20319/mijst.2017.32.514524

Zwickle, A., M. Koontz, T., M. Slagle, K., \& T. Bruskotter, J. (2014). Assessing sustainability knowledge of a student population: Developing a tool to measure knowledge in the environmental, economic and social domains. International Journal of Sustainability in Higher Education, 15(4), 375-389. https://doi.org/10.1108/IJSHE-01-2013-0008 